\title{
Use of Stone Dust in the Design of High Performance Concrete
}

\author{
Joffrey Cheruiyot, Sylvester Ochieng Abuodha, Charles Kabubo \\ SMARTEC, Jomo Kenyatta University of Agriculture and Technology (JKUAT), Nairobi, Kenya \\ Email: joffrey.cheruiyot@gmail.com
}

Received 18 July 2014; revised 8 August 2014; accepted 28 August 2014

Copyright (C) 2014 by authors and Scientific Research Publishing Inc.

This work is licensed under the Creative Commons Attribution International License (CC BY). http://creativecommons.org/licenses/by/4.0/

(c) $\underset{\mathrm{EY}}{\mathrm{BY}}$ Open Access

\section{Abstract}

This research evaluated the suitability of stone dust in the design and production of High Performance Concrete (HPC). HPC mix was designed, tested, costed and a comparison of concrete classes used in the market (Class 25, 30 and 35) done using Cost Benefit Analysis (CBA). The cost benefit was analyzed using Internal Rate of Return (IRR) and Net Present Value (NPV). Laboratory tests established the properties concrete obtained from the design mix. Compressive strength, slump, and modulus of elasticity were tested and analyzed. Structural analysis using BS 8110 was done for a 10 storey office building to establish the structural member sizes. Members obtained from concrete Classes 25, 30, 35 and the new compressive strengths from HPC (Class 80) were obtained and compared. Analysis was done for structural members' sizes and area freed as a result of designing with HPC as well as the steel reinforcement used. To justify the initial cost of HPC if adopted, the Cost Benefit Analysis (CBA) was used to estimate increased costs versus income resulting from increased let table space created. The minimum class of concrete used in design was limited to Class $25 \mathrm{~N} / \mathrm{mm}^{2}$. The research shows that it is possible to manufacture high strength concrete using locally available stone dust. The stone dust sampled from Mlolongo quarries achieved a characteristic strength of $86.7 \mathrm{~N} / \mathrm{mm}^{2}$ at a water cement ratio of 0.32 . With the results structural analysis of a 10 storey office structures with columns spaced at 8 meters center to center was designed using the four classes and results compared. There was a reduction of columns from $1.2 \mathrm{~m}$ wide to $0.65 \mathrm{~m}$ wide (over $45 \%$ ) when concrete class changes from Class 25 to Class 80 creating over $3 \%$ of the total space area per floor. Cost benefit analysis using Net Present Value (NPV) and Internal Rate of Return (IRR) presented business case for the use of HPC. With Class 80, the IRR was at $3 \%$ and NPV being $8 \%$ of the total initial investment. The steel reinforcement increased by 8.64\% using Class 30, 11.68\% using Class 35 and reduced by $8.37 \%$ at Class 80 . Further analysis needs to be done to understand the trend of steel reinforcement keeping all the member sizes the same. In this study the member sizes were optimized based on the steel reinforcement and serviceability. This paper provides useful information to design Engineers and Architects and inform future design of multi storey structures. 


\section{Keywords}

\section{High Performance Concrete (HPC), Locally Produced Quarry Dust, Properties, Cost Benefit Analysis (CBA), Net Present Value (NPV), Internal Rate of Return (IRR)}

\section{Introduction}

More than 40 years have passed since High Performance Concrete was realized; high-strength concrete itself has been enhanced in terms of performance and placeability through a lot of useful developments to the stage that now many applications have been done in North America, Europe, Japan and other countries (Kuwai, T, 2001) [1].

Even though applications of HPC have been greatly used in Japan, Europe and United States of America, little has been done here in Kenya. Research findings, and cost benefits analysis done for the 100 years design life using HPC will provide the engineering practitioners the necessary information for their design. Use of stone dust will also enhance environmental conservation particularly where river sand use will be reduced.

\section{Objectives}

1) Evaluate the suitability of stone dust (quarry waste) in production of High Performance Concrete (HPC).

2) To compare the cost of HPC (Class 80) production against costs of traditional Class 25, 30, and $35 \mathrm{MPa}$.

\section{The Literature Review}

High performance concrete (HPC) is defined as concrete whose strength and durability is greater than those of "normally" obtained concrete (Addis, 2001) [2]. According to United States of America Strategic Highway Research Program on high performance concrete, HPC is defined as having 4 hour compressive strength of greater than or equal to 17.2 Megapscals (Mpa), 24 hour compressive strength of greater than $34.5 \mathrm{Mpa}$ and 28 day compressive strength of greater than $68.9 \mathrm{Mpa}$ (Zia et al., 1991) [3].

High Strength Concrete (HSC) is an example of HPC and according to Japanese Standards of Civil Engineers (JSCE), high strength concrete is any mix with strengths of between 58.0 Mpa to 78.5 Mpa. Although more expensive, per cubic meter, than convectional concrete, it can carry a given load more economically (Rusell et al. 1997) [4].

More than 40 years have passed since High Performance Concrete was realized; high-strength concrete itself has been enhanced in terms of performance and placeability through a lot of useful developments to the stage that now many applications have been done in North America, Europe, Japan and other countries (Kuwai T., 2001) [1].

Since the introduction of concrete with a compressive strength of $62 \mathrm{MPa}$ in columns, shear walls and transfer girders of the Water Tower Place in Chicago in 1975, many applications of HSC in projects, ranging from transmission poles to the tall buildings (KLCC Twin Tower in Kuala Lumpur, Malaysia) with concrete strength reaching up to $131 \mathrm{MPa}$ in the Union Square building in Seattle, Washington have been reported.

In the near future, the high-strength concrete will be prevailing and increasing in use all over the world. The current trend of construction development which has increased over time, there is need to develop economic and environmental friendly construction materials.

There is considerable work done so far on high performance concrete internationally and several research done on stone dust (sometimes referred to as quarry dust) here in Kenya. Stone dust is classified as material obtained from stone crushing process, and due to its fines rarely used in concrete design because of high water cement ratio requirement (Adis, 1991) [5].

Kiliswa (2012), [6] studied the effect of quarry dust on the strengths and permeability of concrete (Class 20 and 25). From his results he concluded that concrete designed with quarry dust as a substitute of river sand had plastic and hardened properties equal to or greater than traditional mixes (aggregate, river sand and cement).

Through the use of high-strength concrete floor, areas can be increased because it allows the sectional area of building columns to be reduced (Jinnai, H. et al., 2005) [7]. Although more expensive, per cubic meter, than convectional concrete, it can carry a given load more economically (Rusell et al. 1997) [4]. 
Whereas there are documented application in Japan, Europe and America, Kenyan construction industry has not embraced the technology. This research will stimulate the discussions around percentage savings in lettable space in highrise buildings when HPC is used in the design. With the strengths of concrete achieved, a typical high-rise building will be designed using Class 25, and 35 and HPC design strength achieved. Structural member sizes will be compared and a cost benefit analysis done for 100 design year period.

\section{The Methodology}

\subsection{Materials Selection}

Stone dust was collected from Athi River crushing plant for testing after stock pile sampling. Ordinary Portland cement (CEM 42.5) and admixture Sika ${ }^{\circledR}$ ViscoCrete ${ }^{\circledR}-\mathrm{HE}$, a water reducer and super plasticizer obtained from the local dealers were used in the design for concrete manufacture.

\subsection{Design and Manufacture and Tests of Concrete (HPC)}

Batching was done by mass for cement and stone dust (American Concrete Institute, 1997) [8] while admixtures in liquid were measured in liters using the conversion factor from the Sika ${ }^{\circledR}$ Visco Crete ${ }^{\circledR}$-HE technical data sheet provided. Mixing was done in a forced action mixer. The use of free fall mixers and hand mixing is not permitted (Addis, 2001) [2].

Sika ${ }^{\circledR}$ ViscoCrete ${ }^{\circledR}-\mathrm{HE}$ a high range water reducing and superplasticizing admixture was used to increase plasticity of fresh concrete. $0.6 \%-0.8 \%$ of the admixture by weight of cement was used.

\subsection{Mixing Method}

Concrete were mixed in a tilting mixer (laboratory type). The following mixing sequence was adopted: stone dust and cement were mixed for 2 minutes; water added during mixing and continuous mix for two more minutes; mixing was stopped for one minute; admixture added to the mix and 3 minutes more minutes mixing.

The methodology adopted was used by Aminul, I.L., in his research Mix Design of High Performance Concrete, National Institute of Technology Silchar, India, 2008 [9]. The methodology was also adopted by Addis. B.J in paper-A method of proportioning trial mixes for high strength concrete published by ACI in 1990 [10].

Slump test, Compressive Strength, and Modulus of Elasticity were tested and results analyzed to get the structural properties of obtained HPC.

11 cubes were cast per mix; 1 for one day test, 2 for seven day test, 4 for twenty eight day test and 4 for one year test (Concrete strength to be checked in a year's time).

\subsection{Structural Design of 10 Storey Structure}

A typical high rise structure (10 floors) was designed using British Standards for reinforced concrete design (BS 8110). Structural member sizes determined for several grades of concrete (Class 25, 30, 35 and 80, the new HPC strength obtained). Ultimate Limit State (ULS) design philosophy was used where serviceability as well as ultimate limit states will be checked. The SLS for deflection considered the performance of the structure under working Loads. The design ensures that the structure, or part of it under consideration, does not deflect excessively causing unsightly cracking and loss of durability.

Figure 1 shows the general layout of the office structure designed, the architect was specific with the column spans at 8 meters center to center. Thus the structure was designed with ribbed slab, 4 meter ribs supported by a slab beam simply supported from the main frame moving across.

\subsection{Cost Benefit Analysis}

The cost of production of HPC (Class 80) was calculated based on optimum design mix obtained from the laboratory tests. This cost was compared with the costs of Class 25, 30, and 35 as available in the market. Further Cost Benefit Analysis (CBA) was undertaken to evaluate the benefit accrued as a result of increased lettable space over the investment incurred. CBA determines the soundness of the investment/decision (justification/ feasibility). It provides a basis for comparing concrete classes.

Total costs comparisons expected for each option against the total expected benefits, to see whether the benefits outweigh the costs, and by how much. 


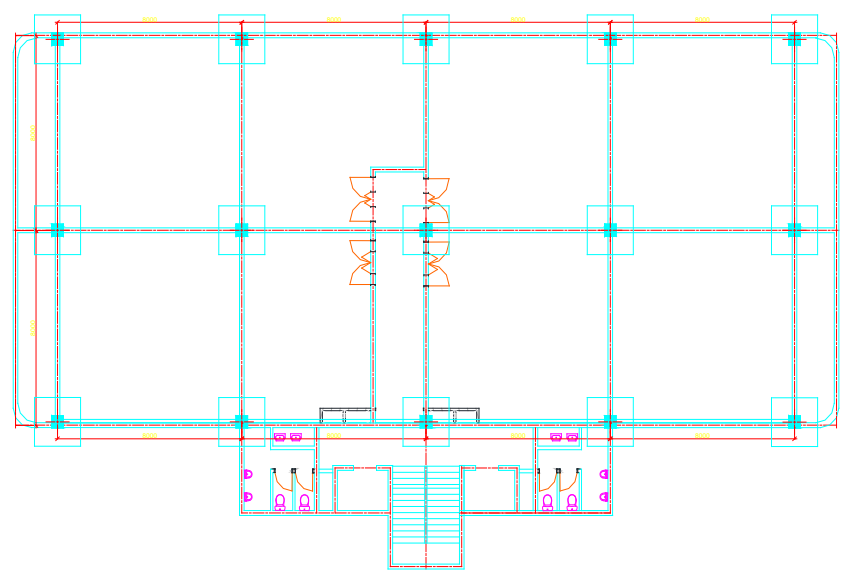

Figure 1. Layout of the structure.

\section{Research Results and Discussion}

\subsection{Data Presentation}

\subsubsection{Material Properties}

Crushed stones was sampled from Mlolongo Quarry and taken to the laboratory for tests. Grading, Finess Modulus (FM), Specific Gravity (SG) and Water Absorption (WA) was tested.

Table 1 and Figure 2 summarizes the material properties of the material used for test.

The material was graded from $75 \mu \mathrm{m}$ to $10 \mathrm{~mm}$ particle size. The samples used had water absorption ratio of 5.8\%, relative density of 2.389 and Finess Modulus of 3.0.

\subsubsection{Design Mix and Results}

5 trial runs were possible from a water cement ratio of $0.42,0.38,0.35,0.32$, and 0.29 beyond which the mix became so dry. The range of water cement ratio for high strength concrete according to Russel et al., 19,774 ranges from 0.42 to 0.25 using stone dust in South Africa.

From the results, maximum strength of $92.7 \mathrm{~N} / \mathrm{mm}^{2}$ (W/C of 0.32 ) was obtained and a minimum of $62 \mathrm{~N} / \mathrm{mm}^{2}$ (W/C of 0.35 ).

Factoring in standard deviation; $\mathrm{fk}=\mathrm{fc}+(1.4 \times$ Standard Deviation $)$, limited to 3.5 based on the laboratory results.

Therefore $92.7=\mathrm{fc}+1.4 \times 3.5$, hence $\mathrm{fc}=87.8 \mathrm{~N} / \mathrm{mm}^{2}$.

To analyze cost benefits of high strength concrete Class 80 were be compared to the common Class 35,30 and $25 \mathrm{~N} / \mathrm{mm}^{2}$.

Table 2 shows the water cement ratio used in design of concrete mixes and the attained compressive strength of concrete cubes at 28 day tests.

The compressive strength results are summarized in Figure 3 and follows the normal trend with increased strength with reduced water cemet ratio. The maximum strength was achieved at a water cement ratio of 0.32 .

Table 3 summarizes the mix designs and the results achieved at 1 day compressive strength for $150 \mathrm{~mm}$ cubes, 7 day test and 28 day tests. It also shows the slump achieved and the mix design details.

\subsubsection{Modulus of Elasticity}

The Average Modulus of elasticity obtained from the results was $49.4 \mathrm{GPa}$, well above the normal concrete range of 20 - 30 GPa. Figure 4 shows stress strain curve for the HPC $150 \mathrm{~mm}$ by $150 \mathrm{~mm}$ cubes tested using a compressive strength machine and a strain gauge. Figure 4 shows the stress in $\mathrm{N} / \mathrm{mm}^{2}$ plotted against strain and Modulus of Elasticity calculated.

\subsubsection{Discussion}

From the results, the optimum mix design is obtained at a water cement ratio of 0.32 with strength of 92.7 $\mathrm{KN} / \mathrm{mm}^{2}$. Factoring in standard deviation; $\mathrm{fk}=\mathrm{fc}+(1.4 \times$ Standard Deviation $)$, limited to 3.5 based on the la- 


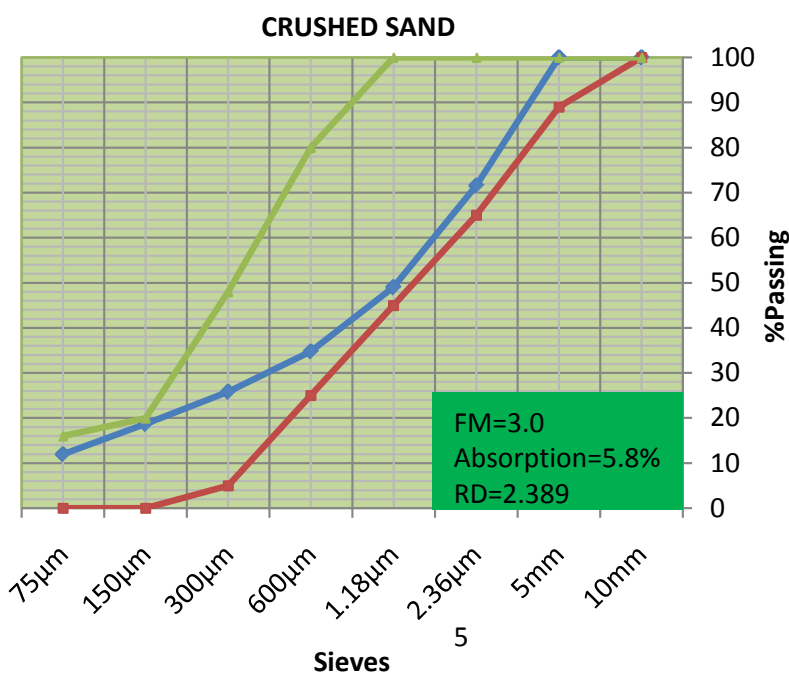

Figure 2. Material properties for stone dust used for concrete design. The green and red lines represent the upper limit and lower limits as per BS specification on crushed sand.

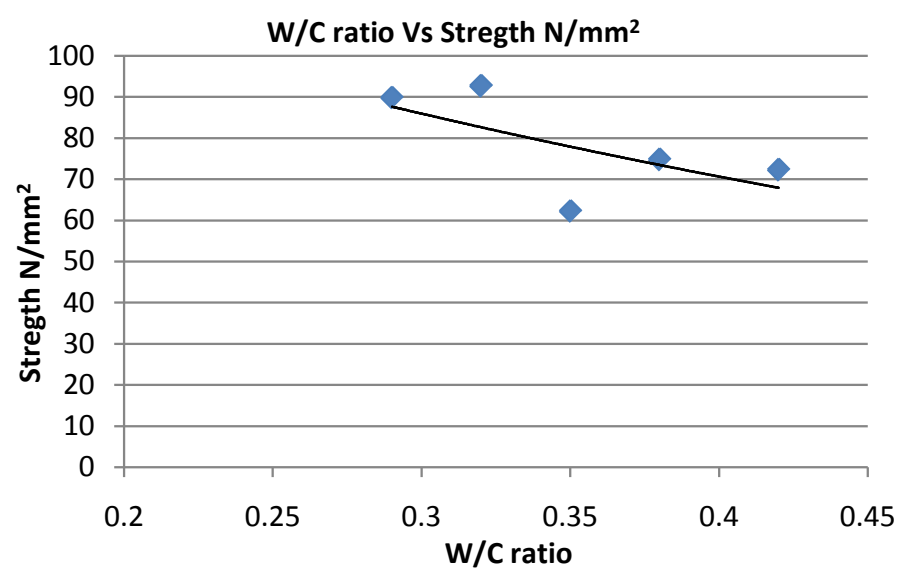

Figure 3. Water cement ratio versus compressive strength obtained.

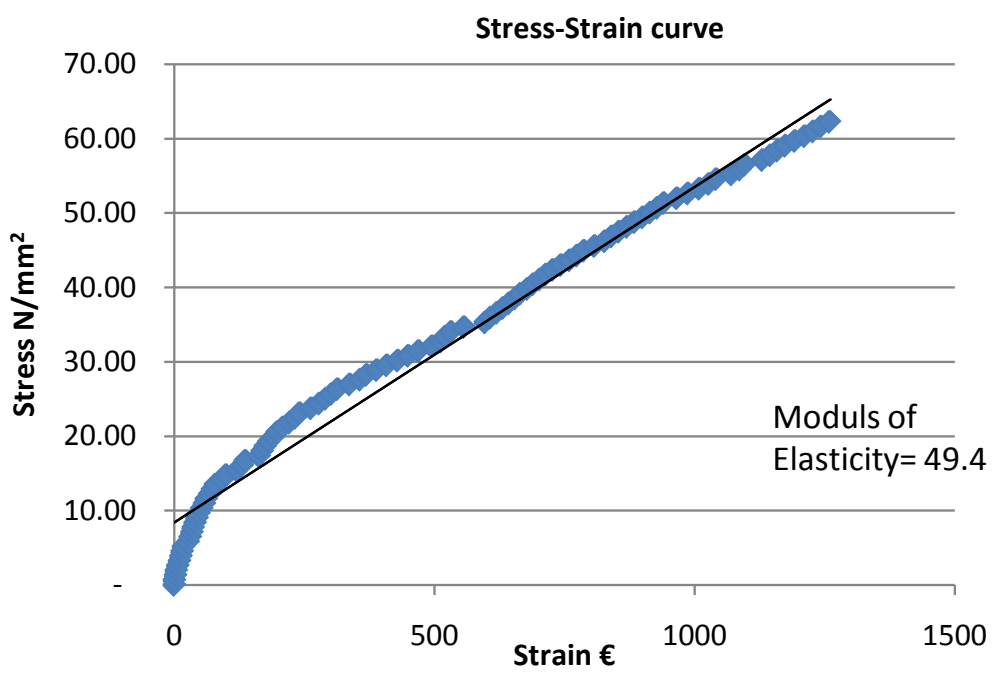

Figure 4. Stress versus strain curve. 
Table 1. Crushed stone dust grading results.

\begin{tabular}{cccc}
\hline \multicolumn{4}{c}{ INDIVIDUAL GRADING CURVES } \\
\hline \\
\% Passing by Weight \\
\hline Sieve sizes & CRUSHED SAND Achieved & LL & UL \\
\hline $10 \mathrm{~mm}$ & 100 & 100 & 100 \\
$5 \mathrm{~mm}$ & 100.0 & 89 & 100 \\
$2.36 \mu \mathrm{m}$ & 71.6 & 65 & 100 \\
$1.18 \mu \mathrm{m}$ & 49.0 & 45 & 100 \\
$600 \mu \mathrm{m}$ & 34.8 & 25 & 80 \\
$300 \mu \mathrm{m}$ & 25.8 & 5 & 48 \\
$150 \mu \mathrm{m}$ & 18.7 & 0 & 20 \\
$75 \mu \mathrm{m}$ & 12.0 & 0 & 16 \\
\hline
\end{tabular}

Table 2. WC rato/Compressive strength obtained.

\begin{tabular}{cc}
\hline W/C Ratio & Strength $\mathbf{N} / \mathbf{m m}^{\mathbf{2}}$ \\
\hline 0.35 & 62.3 \\
0.38 & 74.8 \\
0.42 & 72.3 \\
0.29 & 89.9 \\
0.32 & 92.7 \\
\hline
\end{tabular}

Table 3. Design mixes and laboratory results.

\begin{tabular}{|c|c|c|c|c|c|c|c|c|}
\hline \multicolumn{9}{|c|}{ FIRST BATCH DESIGN } \\
\hline \multirow[t]{2}{*}{ Cement } & Cube ref & Age & Class/mix & Mix Details & Slump & Density & Strength & \multirow{2}{*}{$\begin{array}{l}\text { Average } \\
\left(\mathrm{N} / \mathrm{mm}^{2}\right)\end{array}$} \\
\hline & & & & & $\mathbf{m m}$ & $\mathrm{Kg} / \mathrm{m}^{3}$ & $\mathbf{N} / \mathbf{m m}^{2}$ & \\
\hline \multirow[t]{5}{*}{42.5} & A & 1 & \multirow{5}{*}{ C70-MIX 3} & CEMENT = 595 & \multirow{5}{*}{200} & 2187 & 27.5 & 27.5 \\
\hline & $\mathrm{B}$ & 7 & & C-SAND = 1000 & & 2200 & 60.1 & \multirow{2}{*}{59.0} \\
\hline & $\mathrm{C}$ & 7 & & WATER $=250$ & & 2200 & 58.0 & \\
\hline & $\mathrm{D}$ & 28 & & VISCO = 4.76 & & 2230 & 74.5 & \multirow{2}{*}{73.5} \\
\hline & $\mathrm{E}$ & 28 & & $\mathrm{~W} / \mathrm{C}$ RATIO $=0.42$ & & 2230 & 72.0 & \\
\hline \multirow[t]{5}{*}{42.5} & A & 1 & \multirow{5}{*}{ C70-MIX 2} & CEMENT = 595 & \multirow{5}{*}{180} & 2200 & 25.0 & 25.0 \\
\hline & $\mathrm{B}$ & 7 & & C-SAND = 1318 & & 2210 & 56.5 & \multirow{2}{*}{55.8} \\
\hline & $\mathrm{C}$ & 7 & & WATER $=250$ & & 2230 & 55.0 & \\
\hline & $\mathrm{D}$ & 28 & & VISCO $=3.57$ & & 2230 & 72.5 & \multirow{2}{*}{72.3} \\
\hline & $\mathrm{E}$ & 28 & & $\mathrm{~W} / \mathrm{C}$ RATIO $=0.42$ & & 2240 & 72.0 & \\
\hline \multirow[t]{6}{*}{42.5} & A & 1 & \multirow{6}{*}{ C70-MIX 4} & CEMENT = 595 & \multirow{6}{*}{125} & 2195 & 24.0 & \multirow{2}{*}{24.0} \\
\hline & $\mathrm{B}$ & 1 & & C-SAND = 1318 & & 2200 & 24.0 & \\
\hline & $\mathrm{C}$ & 7 & & WATER = 211 & & 2170 & 47.0 & \multirow[b]{2}{*}{47.5} \\
\hline & $\mathrm{D}$ & 7 & & VISCO $=3.57$ & & 2170 & 48.0 & \\
\hline & $\mathrm{E}$ & 28 & & $\mathrm{~W} / \mathrm{C}$ RATIO $=0.35$ & & 2160 & 62.0 & \multirow[b]{2}{*}{62.3} \\
\hline & $\mathrm{F}$ & 28 & & & & 2210 & 62.5 & \\
\hline
\end{tabular}




\section{Continued}

\begin{tabular}{|c|c|c|c|c|c|c|c|c|}
\hline \multirow[b]{2}{*}{ Cement } & \multicolumn{7}{|c|}{ SECOND BATCH TESTS } & \multirow[b]{2}{*}{$\begin{array}{l}\text { Average } \\
\left(\mathrm{N} / \mathrm{mm}^{2}\right)\end{array}$} \\
\hline & Cube ref & Age & Class/mix & Mix details & $\begin{array}{c}\begin{array}{c}\text { Slump } \\
\text { achieved }\end{array} \\
\text { mm }\end{array}$ & $\begin{array}{l}\text { Density } \\
\text { KG/M3 }\end{array}$ & $\begin{array}{l}\text { Strength } \\
\text { N/MM2 }\end{array}$ & \\
\hline \multirow[t]{6}{*}{42.5} & A & 7 & \multirow{6}{*}{ C70-MIX 7} & CEMENT = 657.9 & \multirow{6}{*}{240} & 2232.3 & 49.7 & \multirow{2}{*}{48.0} \\
\hline & B & 7 & & C-SAND = 1225 & & 2210.4 & 44.8 & \\
\hline & $\mathrm{C}$ & 28 & & WATER = 198.4 & & 2226.1 & 74.3 & \multirow{4}{*}{74.7} \\
\hline & $\mathrm{D}$ & 28 & & VISCO $=52.5$ & & 2233.5 & 75.2 & \\
\hline & $\mathrm{E}$ & 28 & & $\mathrm{~W} / \mathrm{C}$ RATIO $=0.38$ & & 2224.0 & 74.2 & \\
\hline & $\mathrm{F}$ & 28 & & & & 2249.2 & 75.0 & \\
\hline \multirow[t]{6}{*}{42.5} & A & 7 & \multirow{6}{*}{ C70-MIX 6} & CEMENT = 781 & \multirow{6}{*}{220} & 2258.4 & 64.5 & \multirow{2}{*}{65.5} \\
\hline & B & 7 & & C-SAND $=1170$ & & 2254.8 & 66.8 & \\
\hline & $\mathrm{C}$ & 28 & & WATER $=198.4$ & & 2321.2 & 92.3 & \multirow{4}{*}{92.7} \\
\hline & D & 28 & & VISCO $=62.5$ & & 2325.9 & 92.6 & \\
\hline & $\mathrm{E}$ & 28 & & $\mathrm{~W} / \mathrm{C}$ RATIO $=0.32$ & & 2337.5 & 93.0 & \\
\hline & $\mathrm{F}$ & 28 & & & & 2330.1 & 92.9 & \\
\hline \multirow[t]{6}{*}{42.5} & A & 7 & \multirow{6}{*}{ C70-MIX 5} & CEMENT = 862.1 & \multirow{6}{*}{200} & 2273.8 & 60.0 & \multirow{2}{*}{62.0} \\
\hline & B & 7 & & C-SAND $=1100$ & & 2285.3 & 63.7 & \\
\hline & $\mathrm{C}$ & 28 & & WATER = 198.4 & & 2341.0 & 90.1 & \multirow{4}{*}{89.9} \\
\hline & D & 28 & & VISCO $=69.0$ & & 2346.7 & 90.0 & \\
\hline & E & 28 & & $\mathrm{~W} / \mathrm{C}$ RATIO $=0.29$ & & 2337.5 & 89.7 & \\
\hline & $\mathrm{F}$ & 28 & & & & 2340.1 & 89.8 & \\
\hline \multirow[t]{6}{*}{42.5} & A & 7 & \multirow{6}{*}{ C70-MIX 7} & CEMENT $=657.9$ & & 2213.9 & 46.0 & \multirow{2}{*}{46.0} \\
\hline & $\mathrm{B}$ & 7 & & C-SAND = 1225 & & 2213.0 & 46.3 & \\
\hline & $\mathrm{C}$ & 28 & & WATER $=198.4$ & & 2269.3 & 61.5 & \multirow{4}{*}{60.4} \\
\hline & $\mathrm{D}$ & 28 & & VISCO $=5.25$ & 110 & 2229.0 & 61.2 & \\
\hline & $\mathrm{E}$ & 28 & & $\mathrm{~W} / \mathrm{C}$ RATIO $=0.38$ & & 2270.2 & 61.6 & \\
\hline & $\mathrm{F}$ & 28 & & & & 2236.7 & 57.4 & \\
\hline
\end{tabular}

boratory results the characteristic $87.8 \mathrm{~N} / \mathrm{mm}^{2}$ Compressive Strength is obtained. For design and cost benefits analysis Class 80 was subsequently used.

\subsubsection{Structural Design}

A typical structure was analyzed to obtain all the structural members. The analyzed building has ten storeys and a size of $38.6 \mathrm{~m}$ by 22.6 meters with floor spans of $8 \mathrm{~m}$ by $8 \mathrm{~m}$. Since the floor spans are large, ribbed slab was designed for the $8 \mathrm{~m}$ by $8 \mathrm{~m}$; the entire remaining floor spaced used a common $150 \mathrm{~mm}$ slab.

Structural members were obtained as outlined in Table 4.

The volume of concrete and steel reinforcement was also calculated from the members and it was established that concrete volume reduces by $29.9 \%$ when concrete strength is increased from Class 25 to Class 80 .

Figure 5 shows volume of concrete in structural members and the total reinforcement required for the structure. 


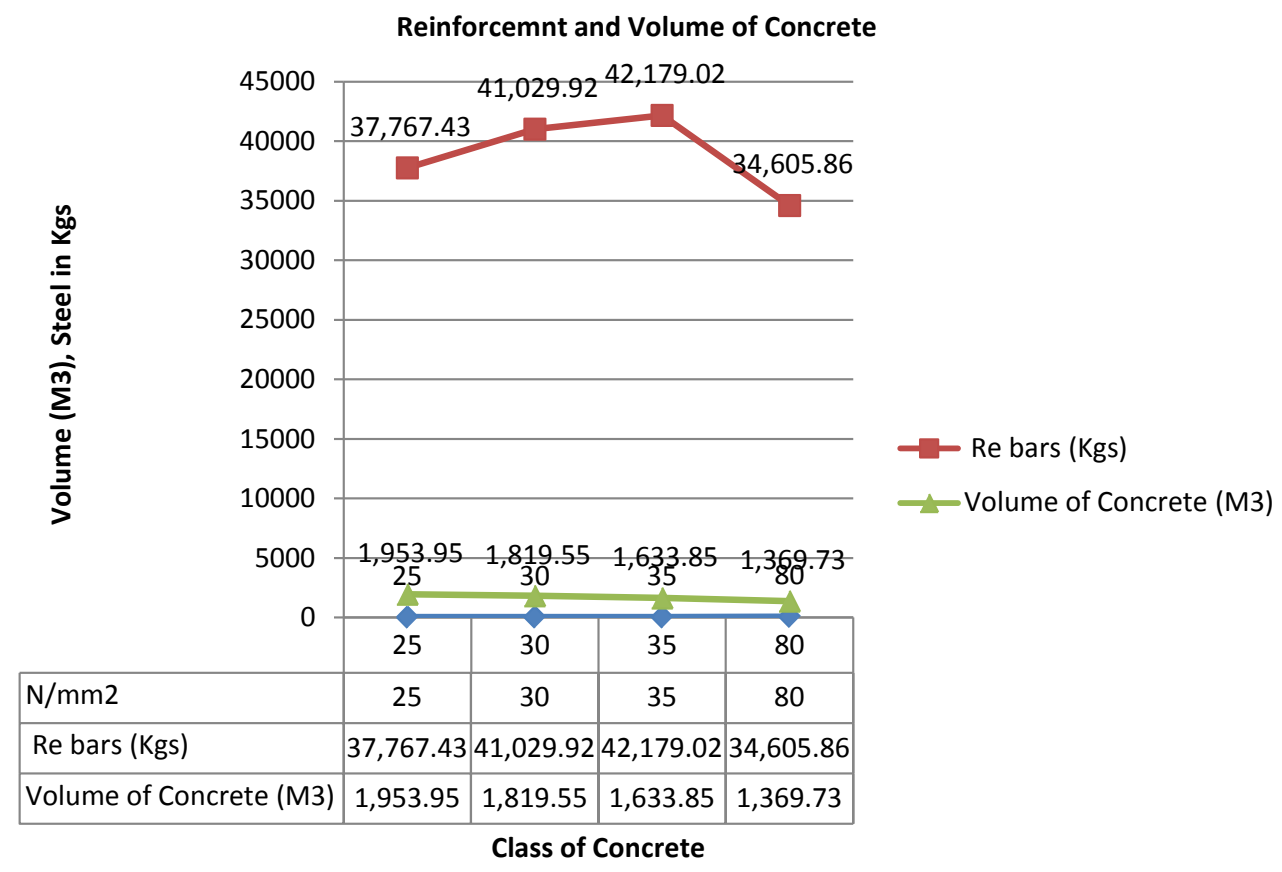

Figure 5. Comparison between volume of concrete and reinforcement steel.

Table 4. Structural member sizes obtained from the structural design.

\begin{tabular}{|c|c|c|c|c|c|c|}
\hline \multicolumn{7}{|c|}{ STRUCTURAL MEMBER SIZES } \\
\hline \multirow{2}{*}{$\#$} & \multirow{2}{*}{ Structural Member } & \multirow{2}{*}{ Size $(\mathbf{m m})$} & \multicolumn{4}{|c|}{ Concrete Class (N/mm²) } \\
\hline & & & 25 & 30 & 35 & 80 \\
\hline \multirow[b]{2}{*}{1} & \multirow[b]{2}{*}{ Internal Colums } & $\mathrm{b}$ & 1200 & 1000 & 900 & 650 \\
\hline & & $\mathrm{h}$ & 1200 & 1000 & 900 & 650 \\
\hline \multirow{2}{*}{2} & \multirow{2}{*}{ External Columns } & $\mathrm{b}$ & 1000 & 900 & 800 & 500 \\
\hline & & $\mathrm{h}$ & 1000 & 900 & 800 & 500 \\
\hline 3 & Internal Column bases & hf & 400 & 400 & 400 & 400 \\
\hline 4 & External Column bases & hf & 250 & 250 & 250 & 250 \\
\hline \multirow[b]{2}{*}{5} & \multirow[b]{2}{*}{ Beams (ribbed slab)-4 m long-320 No } & $\mathrm{b}$ & 125 & 125 & 125 & 125 \\
\hline & & $\mathrm{h}$ & 250 & 250 & 200 & 200 \\
\hline \multirow{2}{*}{6} & \multirow{2}{*}{ Slab beam-8 m long } & $\mathrm{b}$ & 500 & 500 & 500 & 500 \\
\hline & & $\mathrm{h}$ & 250 & 250 & 250 & 200 \\
\hline \multirow{2}{*}{7} & \multirow{2}{*}{$\begin{array}{l}\text { Secondary beams } \\
\text { (supporting slab beam-8 m long-4 No }\end{array}$} & $\mathrm{b}$ & 200 & 200 & 200 & 200 \\
\hline & & $\mathrm{h}$ & 450 & 450 & 450 & 300 \\
\hline \multirow{2}{*}{8} & \multirow{2}{*}{ Main frame Beam-8 m long-10 No } & $\mathrm{b}$ & 200 & 200 & 200 & 200 \\
\hline & & $\mathrm{h}$ & 600 & 600 & 450 & 425 \\
\hline \multirow[b]{2}{*}{9} & \multirow[b]{2}{*}{ External Beam-8 m long-12 N0 } & $\mathrm{b}$ & 200 & 200 & 200 & 200 \\
\hline & & $\mathrm{h}$ & 450 & 450 & 350 & 250 \\
\hline 10 & Slab & hf & 150 & 150 & 150 & 150 \\
\hline
\end{tabular}


Figure 5 details the volume of concrete used in structural members when Class 25, 30, 35 and 60 is used as well as the weight of steel reinforcement required.

The volume of concrete reduces from 1953 when Class 25 is used to 1369 when Class 80 is used. The weight of steel reinforcement increases from Class 30 and Class 40 and drops significantly when Class 80 is used.

Floor area was calculated factoring in the area taken by the columns and it was established that additional $1.5 \%\left(13.4 \mathrm{~m}^{2}\right.$ of $\left.874 \mathrm{~m}^{2}\right)$ of the floor area was added per floor when concrete strength was increased from Class 25 to Class 80. Table 5 summarizes freed space in the structure. The floor area will bring in additional income from the lease throughout the life cycle of the structure.

\subsubsection{Cost Benefit Analysis}

Internal rate of return (IRR) was calculated based on current concrete costs, cost of steel and projected earnings from the extra space obtained from reducing the structural members. The internal rate of return on an investment or project is the "annualized effective compounded return rate" or "rate of return" that makes the net present value (NPV as $N P V=\sum_{t=1}^{t} \frac{C t}{(1+t)^{t}}-C o$ ) of all cash flows (both positive and negative) from a particular investment equal to zero.

$$
N P V=\sum_{t=1}^{t} \frac{C t}{(1+t)^{t}}-C o
$$

where,

$C_{t}$ is the net cash in flow;

$C_{o}$ is the initial investment;

$r$ is the discount rate;

$t$ is the time in years.

The IRR for Class $80 \mathrm{~N} / \mathrm{mm}^{2}$ was found to be 3\% which reduces to $2 \%$ for Class $35 \%$ and $30 \%$ and $0 \%$ for Class 25.

Table 6 summarizes the NPV and IRR. The results shows that whereas the initial cost investments for Class 80 concrete is the highest, the net present value is lower and comparable with using Class 35 . The internal rate of return for using Class 80 is 3\% and thus show that it makes business sense to use Class 80 concrete.

Table 5. Area freed from use of smaller members and estimated returns.

\begin{tabular}{|c|c|c|}
\hline Concrete Class & \multirow{2}{*}{ Total Additional Area $\left(\mathrm{m}^{2}\right)$} & \multirow{2}{*}{ Benefits-Returns $/ \mathbf{m}^{2}$ (KES)/month } \\
\hline $\mathbf{N} / \mathbf{m m}^{2}$ & & \\
\hline 25 & - & - \\
\hline 30 & 67 & $59,895.00$ \\
\hline 35 & 96 & $86,355.00$ \\
\hline 80 & 134 & $120,375.00$ \\
\hline
\end{tabular}

${ }^{*}$ Class 25 is the minimum class of concrete and the base used for analysis; ${ }^{*}$ The cost of hiring space estimated at KES $850 / \mathrm{m}^{2}$ per month (Average market price in the CBD-Nairobi).

Table 6. Cost benefit analysis presentation.

\begin{tabular}{cccc}
\hline $\begin{array}{c}\text { Concrete Class } \\
\text { N/mm } \mathbf{m}^{\mathbf{2}}\end{array}$ & $\begin{array}{c}\text { Current Price for Construction } \\
\text { (KES) }\end{array}$ & Net Present Value (NPV) & $\begin{array}{c}\text { Internal Rate } \\
\text { of Return (IRR) }\end{array}$ \\
\hline 25 & $31,887,391$ & $31,887,391$ & $0 \%$ \\
30 & $33,718,185$ & $32,412,497$ & $2 \%$ \\
35 & $37,738,483$ & $35,855,978$ & $2 \%$ \\
80 & $38,114,759$ & $35,490,631$ & $3 \%$ \\
\hline
\end{tabular}




\subsection{Summary}

Quarry dust obtained from Mlolongo quarry graded between $75 \mu \mathrm{m}$ to $19 \mathrm{~mm}$ with a relative density of 2.389 $\mathrm{Kg} / \mathrm{m}^{2}$ make good high strength concrete of over $80 \mathrm{~N} / \mathrm{mm}^{2}$ at a water cement ratio of 0.32 . The concrete manufactured used Sika ${ }^{\circledR}$ ViscoCrete ${ }^{\circledR}$-HE admixture which is a plasticizer and water reducer to minimize the water requirement and achieve the required slump.

Stone dust is much cheaper than both course aggregate and sand and therefore minimize the cost of concrete which has high cement volume per tonne $\left(780 \mathrm{~kg} / \mathrm{m}^{3}\right.$ from the mix design).

Design of structures using high strength concrete reduces significantly the structural member sizes, steel reinforcement and increase the available usable space in the structure. The limitations for reduced structural members are modulus of elasticity particularly for slender columns and shear reinforcements for foundation footing and heavily loaded beams.

There is significant return on investment when high strength of concrete is used for structural members (in the case of construction of 10 storey structure, the IRR was 3\%). Use of HPC present additional advantages; in the case where the client has a small space and needs bigger floor area or in the case where the floor areas have big spans (architectural requirements of spaced columns).

\subsection{Conclusions}

From the research the following conclusion can be made:

- Manufacture High strength concrete (HPC) using locally available stone dust is possible with strengths of over $80 \mathrm{kN} / \mathrm{mm}^{2}$ with a Modulus of Elasticity of $49.4 \mathrm{Gpa}$ achieved using stone dust obtained from Mlolongo Quarries.

- Use of High strength concrete significantly reduces structural members (columns sizes, beam depths). The sizes are however limited by modulus of elasticity particularly for slender columns and shear reinforcement for heavily loaded columns and foundation pads.

- There is also significant reduction in the total weight of reinforcement steel when high strength concrete is used.

- The benefits accrued from letting extra space created from the smaller column sizes are significant and present a business case when life cycle costs of the structure are considered. This is important for clients who have smaller development space and want to maximize it or for structure that have bigger floor spans.

\subsection{Recommendations}

The construction industry needs to consider use of high strength concrete (HPC) in the current market as it will greatly improve the construction standards. There is enough justification for its use in high storey structures especially in rapidly congested areas of the cities where land has reduced.

Use of HPC will also help architects improve their designs particularly where they require big spaces or minimum columns at the centre of the structure.

Use of stone dust will also reduce river sand use which has in the recent past presented serious environmental impacts in the rivers where they are mined.

\subsection{Areas of Further Study}

As the laboratory work came to an end during this study, Bamburi Cement a leading manufacturing company in Kenya introduced Ordinary Portland Cement Class 52.5. It will be important to see how the new product will enhance the concrete strengths.

There is need to comprehensively look at the relationship between reinforcements and class of concrete keeping all the structural members constant. In this study, where there was significant reduction of steel, like in the case of beams when compressive reinforcement was not required, the structural member was reduced for it to have more economic sense.

It will also be interesting to study unreinforced concrete beams using HPC. Modulus of rapture will be obtained and compared using the existing formulae.

\section{References}

[1] Kuwai, T. (2001) State-of-the-Art Report on High-Strength Concrete in Japan Recent Developments and Applications. 
105-8007, 88 .

[2] Addis, B. and Owens. G. (2001) Fulton's Concrete Technology. 8th Edition. Cement \& Concrete Institute, Midrand, South Africa.

[3] Zia, P., Leming, M.L., Ahmad, S.H., Shemel, J.J., Elliot, R.P. and Naaman, A.E. (1991) Mechanical Behavior of High Strength Concrete, Strategic Highway Research Program, High Performance Concretes, a State of the Art report, SHRP National Research Council, Washington DC.

[4] Russel, H. and Moreno, J. (1977) State-of-the-Art Report on High Strength Concrete, Chicago Committee on HighRise Buildings.

[5] Addis, B.J. (1991) Properties of High-Strength Concrete Concrete Made with South African Materials. Ph.D. Thesis, University of Witwatersand, Jonanesburg.

[6] Kiliswa, M. (2011) Effect of Quarry Dust on the Strengths and Permeability of Concrete. Msc Thesis, University of Nairobi, Kenya.

[7] Jinnai, H. (2005) Development and Construction Record on High Strength Concrete with the Compressive Strength Exceeding 150MPa, ACI SP-228, Seventh International Symposium on the Utilization of High-Strength/High-Performance Concrete, 1045-1062.

[8] American Concrete Institute 211.1-9191997, Standard Practice for Selecting Proportions for normal, heavyweight, and mass concrete, Farmington Hills, Michigan: American Concrete Institute, 1997.

[9] Aminul, I.L. (2008) Mix Design of High Performance Concrete, National Institute of Technology Silchar-788010, India.

[10] Addis. B.J. and Alexander, M.G. (1990) A Method of Proportioning Trial Mixes for High Strength Concrete, High Strenth Concrete, Second International Symposium, Berkeley, California, 227-278 (ACI special Publication, SP-121). 
Scientific Research Publishing (SCIRP) is one of the largest Open Access journal publishers. It is currently publishing more than 200 open access, online, peer-reviewed journals covering a wide range of academic disciplines. SCIRP serves the worldwide academic communities and contributes to the progress and application of science with its publication.

Other selected journals from SCIRP are listed as below. Submit your manuscript to us via either submit@scirp.org or Online Submission Portal.
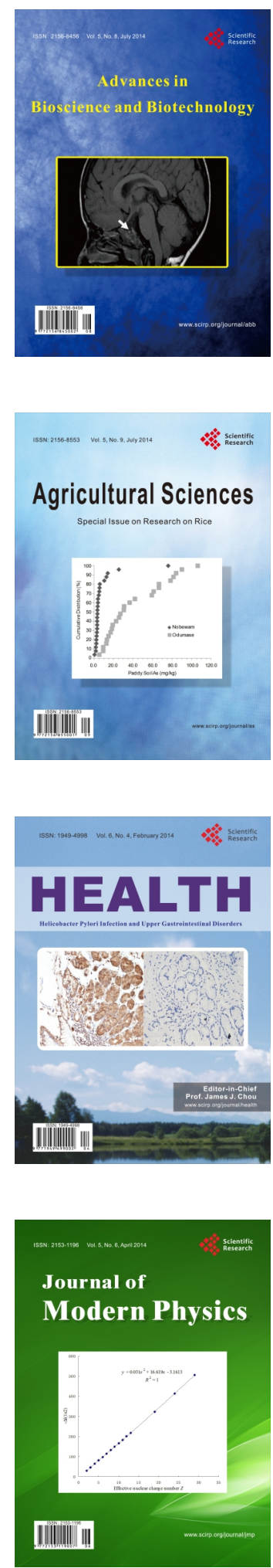
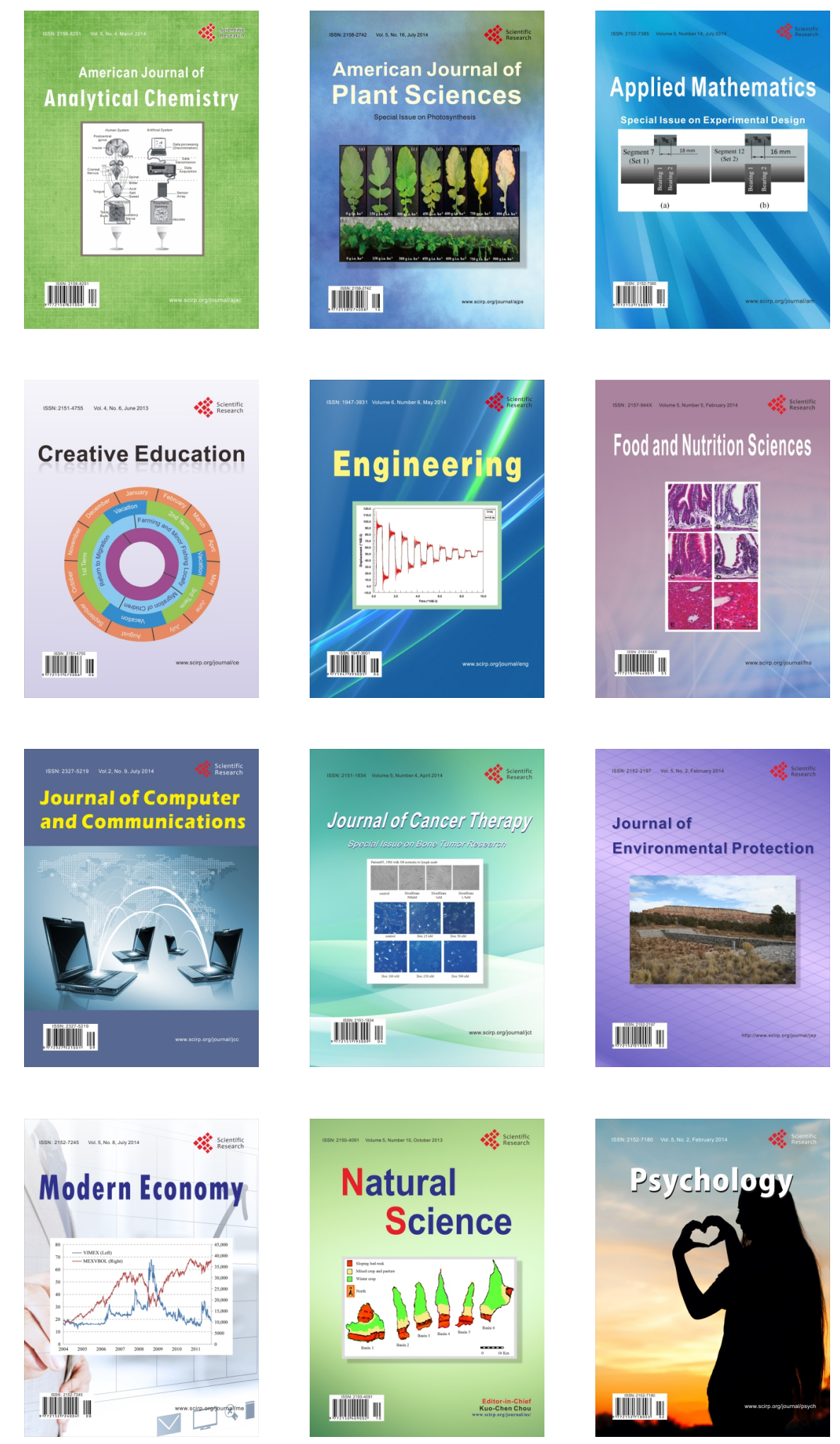